\section{Erythrocytosis induced by danazol in an anephric patient}

An anephric patient undergoing continuous ambulatory peritoneal dialysis developed erythrocytosis after treatment of menorrhagia with danazol; this was associated with a high serum immunoreactive erythropoietin concentration, presumably of hepatic origin. This may suggest a use for danazol in the treatment of refractory anaemias.

\section{Case report}

A white woman with end stage renal failure due to reflux nephropathy started regular haemodialysis in 1972 when aged 17. Both kidneys were removed in 1973 because of persistent infection and hypertension; this led to severe anaemia, which was exacerbated by occult bleeding from a gastric ulcer. She transferred from haemodialysis to continuous ambulatory peritoneal dialysis in 1982 but remained anaemic with a haemoglobin concentration of $45-65 \mathrm{~g} / \mathrm{l}$, and by 1983 had developed iron overload from multiple transfusions (serum ferritin concentration $>5000 \mu \mathrm{g} / \mathrm{l}$ ). In 1983 her transfusion requirement was increased by menorrhagia; this failed to respond to norethisterone and in October 1984 she started danazol $400 \mathrm{mg}$ daily. During the next four months her menstrual loss was completely suppressed, but she became depressed, lethargic, and increasingly obese. In February 1985, after a short illness with headache, loss of concentration, and pruritus, she developed a dense right sided hemiparesis. Her haemoglobin concentration was $179 \mathrm{~g} / \mathrm{l}$; this increase was not due to haemoconcentration as there was no clinical evidence of fluid depletion. The blood film and bone marrow aspirate gave no evidence of a primary myeloproliferative disorder. She died five days later, and necropsy showed a brain stem haemorrhage and moderate iron deposition in the liver but no recognised cause of secondary polycythaemia.

The serum immunoreactive erythropoietin concentration at the time of her final admission was $56 \mathrm{mIU} / \mathrm{ml}$ (range for normal blood donors $13-37 \mathrm{mIU} / \mathrm{ml}$ ) this was indistinguishable from renally derived erythropoietin, as shown by parallel dose response curves of the patient's serum, normal sera, and the international reference preparation of erythropoietin.

\section{Comment}

The impairment of erythropoiesis in uraemia results from inadequate erythropoietin production and retention of inhibitory factors by the diseased kidneys. Anaemia tends to be more noticeable in anephric patients as they are dependent on extrarenal sites such as the liver to produce erythropoietin. A sensitive radioimmunoassay can detect erythropoietin in these patients and in this case showed that the serum erythropoietin concentration was inappropriately high for the haemoglobin concentration. ${ }^{1}$ This implies that our patient's erythrocytosis resulted from overproduction of extrarenal erythropoietin, and the temporal relation with the start of danazol treatment suggests that this was drug induced. An additional direct effect of danazol on the bone marrow is not excluded.

Androgens stimulate erythropoiesis by increasing the serum erythropoietin concentration and by a direct effect on the bone marrow so that in uraemic patients with adequate iron stores anaemia may be fully reversed. ${ }^{2}$ Unfortunately, anephric patients do not always respond to androgens and the improvement in anaemia is not generally as good. ${ }^{3}$ This finding, combined with a high incidence of virilising side effects, has limited their usefulness in uraemic patients. Danazol is an isoxazol derivative of $17 \alpha-$ ethinyltestosterone which has the advantage of being relatively nonvirilising. Chimbira et al gave $400 \mathrm{mg}$. daily and successfully induced amenorrhoea in 18 patients with menorrhagia. ${ }^{4}$ Although the improvement in these patients' anaemia was ascribed to enhanced erythropoiesis, danazol has not been widely used in the management of refractory anaemia.

The mechanism by which androgens increase extrarenal erythropoietin production remains unclear, although Meyrier $e t$ al have suggested that it is a result of their hepatotoxicity, erythropoietin being secreted by injured hepatocytes. ${ }^{5}$ This mechanism can be excluded in this patient since the liver was histologically normal apart from mild iron deposition.

Although the physiological role of extrarenal erythropoietin is uncertain, this evidence of its biological activity and the possibility of stimulation by pharmacological means such as danazol warrants further investigation.

We thank Dr P M Cotes for the erythropoietin determination.

1 Cotes PM. Immunoreactive erythropoietin in serum. $\mathrm{Br} f$ Haematol 1982;50:427-38.

2 Schustack A, Meshiaj D, Waiss Z, Gotloib L. Intramuscular iron replenishment and replacement combined with testosterone ethanate in maintenance hemodialysis anemia: a follow-up of up to 8 years on 16 patients. Clin Nephrol 1985;23:303-6.

3 Fried W, Jonasson O, Lang G, Schwartz F. The hematologic effect of androgens in uremic patients. Study of packed cell volume and erythropoietin responses. Ann Intern Med 1973;79:823-7.

4 Chimbira TH, Cope E, Anderson ABM, Bolton FG. The effects of danazol on menorrhagia, coagulation mechanisms, haematological indices and body weight. $\mathrm{Br}$ f Obstet Gynaeco $1979 ; 86: 46-50$
5 Meyrier A, Simon P, Boffa G, Brissot P. Uremia and the liver. 1. The liver and erythropoiesis in chronic renal failure. Nephron 1981;29:3-6.

(Accepted 11 December 1986)

St Peter's Hospitals and Institute of Urology, St Philip's Hospital, London WC2A 2EX

I K BARTON, MA, MRCP, lecturer

M A MANSELL, MD, MRCP, consultant nephrologist

Correspondence to: Dr Barton.

\section{Antibodies to Campylobacter pyloridis in household contacts of infected patients}

There is considerable interest and controversy about the role of the gastric campylobacter like organism Campylobacter pyloridis in the pathogenesis of upper gastrointestinal lesions such as gastritis and peptic ulceration. ${ }^{1}$ How some individuals became infected or colonised and the source of these organisms that inhabit gastric mucus are entirely unknown. We thought that a study of the household contacts of infected individuals might throw some light on the epidemiology of this infection.

\section{Patients, methods, and results}

We studied the household contacts of 40 patients (age 21-75, mean 48 ) in whom $C$ pyloridis had been cultured from a gastric biopsy specimen. The diagnosis in the index patients was gastritis in 26, peptic ulcer in nine, and oesophagitis in five. The study population consisted of 26 consanguineous contacts-brothers, sisters, and children (age 11-52, mean 21)-and 38 non-consanguineous contacts, all of them spouses (age 29-82, mean 51). Serum samples were examined for complement fixing antibodies as described. ${ }^{2}$ All the index patients had antibodies but only three $(12 \%)$ of the consanguineous and eight $(21 \%)$ of the nonconsanguineous contacts were positive.

\section{Comment}

The gastric campylobacter like organism is highly adapted for existence in gastric mucus and has not yet been reported from any other site. The prevalence of antibody to this organism, and therefore also colonisation or infection, increases with age, ${ }^{34}$ implying that acquisition occurs with increasing frequency as we grow older.

The mode of transmission of such a specialised organism is unknown and also difficult to imagine. In this study we selected a group of index patients who were colonised with the organism and looked at their household contacts for evidence of infection. Only eight of the 38 spouses had antibodies, whereas all the patients did so. The ages of the spouses were similar to those of the index patients, and a prevalence of antibody of about $40 \%$ would have been expected in this age group. ${ }^{3}$ Clearly transmission of this organism does not occur to any significant extent among spouses.

In our previous survey $12 \%$ of a random sample of the population aged 21 30 had antibody to the gastric campylobacter like organism, a figure close to that of consanguineous contacts in this study. The absence of an increased prevalence of antibodies in blood relatives indicates that opportunities for transmission do not seem to exist within the household but also that genetic factors that might predispose to infection may be relatively unimportant.

1 Marshall BJ. Campylobacter pyloridis and gastritis. $\mathcal{I}$ Infect Dis 1986;153:650-7.

Jones DM, Lessells AM, Eldrige J. Campylobacter-like organisms on the gastric mucosa: culture histological and serological studies. $\mathcal{F}$ Clin Pathol 1984;37:1002-6.

3 Jones DM, Eldridge J, Fox AJ, Sethi P, Whorwell PJ. Antibody to the gastric campylobacter-like organism (Campylobacter pyloridis), clinical correlations and distribution in the norma population. $f$ Med Microbiol 1986;22:57-62.

4 Hutchinson DN, Bolton FJ, Hinchcliffe PM, Holt AV. Distribution in various clinical groups of antibody to Campylobacter pyloridis detected by ELISA, complement and microagglutination tests. In: Pearson AD, Skirrow MB, Lior H, Rowe B, eds. Campylobacter III. Proceedings of the third international workshop on campylobacter infections. London: PHLS, 1985:185.

(Accepted 18 December 1986)

Public Health Laboratory and Department of Medicine, University Hospita of South Manchester, Manchester M20 8LR

D M JONES, MD, FRCPATH, director, public health laboratory

JOAN ELDRIDGE, FIMLS, senior medical laboratory scientific officer

P J WHORWELL, MD, MRCP, consultant physician and senior lecturer in medicine

Correspondence to: Dr Jones. 